\title{
Students' Interest in Vocational Schools as the Dimension of Being in a Wellbeing School Model
}

\author{
Aniq Hudiyah Bil Haq ${ }^{1,}$, Yogiek Indra Kurniawan ${ }^{2}$, Tri Astuti ${ }^{1}$, Kumaidi ${ }^{3}$ \\ ${ }^{1}$ Department of Psychology, Universitas Muhammadiyah Kalimantan Timur, Samarinda, Indonesia \\ ${ }^{2}$ Department of Informatics Engineering, Universitas Jenderal Soedirman, Purwokerto, Central Java, Indonesia \\ ${ }^{3}$ Department of Psychology, Universitas Muhammadiyah Surakarta, Surakarta, Central Java, Indonesia
}

Email address:

ahbh186@umkt.ac.id (A. H. B. Haq)

${ }^{*}$ Corresponding author

\section{To cite this article:}

Aniq Hudiyah Bil Haq, Yogiek Indra Kurniawan, Tri Astuti, Kumaidi. Students' Interest in Vocational Schools as the Dimension of Being in a Wellbeing School Model. International Journal of Vocational Education and Training Research. Vol. 5, No. 2, 2019 , pp. 43-47.

doi: $10.11648 / j . i j v e t r .20190502 .11$

Received: February 19, 2019; Accepted: July 13, 2019; Published: August 19, 2019

\begin{abstract}
The purpose of this research is to identify the students' interest in vocational schools as the dimension of being in a well-being model school. A questionnaire was used to measure students' subjective perceptions. Suitability Vocational interests are assessed using a standardized test known as a modified vocational interest scale from the SDS (Self-directed search). Eleven vocational schools in Indonesia, comprising of 362 students from the manufacturing program contributed in the survey. The computer-based statistical data analysis system was used to examine the raw data collection. The results showed that $49 \%$ of the students felt satisfied and enjoyed the learning process they followed at school. Considering the students' interest in the vocational school, which conforms to the personality typology, $41 \%$ of the students were confirmed positively. The two statistic figures suggest that when a student has strong motivation and has a high interest in the vocational school, they feel positive about the education process. Besides student also enjoy and follow the system accordingly. The development of well-being in school can then be shaped. This paper provides the implementation of a well-being model to cater to the education process, considering the conformance of students' interest in their selected course programs in vocational schools.
\end{abstract}

Keywords: Interest, School Well-Being, Manufacturing, Vocational

\section{Introduction}

Well-being at school is extremely important for the individual development of students and the vocational school. In this study, the conceptual model of well-being in schools is grounded from Allardt's theory of welfare. There are four dimensions, namely having (school conditions), loving (social relationships), being (means for selffulfillment), and health status [1]. This study focuses on one dimension, the dimension of being. Allard [1] formulated the cross-tabulation of being, with the objective and subjective indicators of well- person, where being refers to the students' needs for personal growth [1]. The students' relation identifies the objective indicators with society and nature. The subjective indicators include the students' feeling of alienation, personal growth, and enjoyment during the study process which needs to be identified by the teachers and other related parties.

Taking a specific domain approach to well-being, some researchers have proposed a model for studying children' experiences, particularly in the context of school (school wellbeing). Conceptualized school well-being as an emerging form of the relation between students' satisfaction of school, positive affect in school, and negative affect in school. School satisfaction refers to a global cognitive evaluation of school life, which emerges from a student's day-to-day school experiences [2]. One study regarding well-being at school found that well-being is important for student's academic performance. Especially in the dimensions of being and having, self- efficacy as the aspect of being and student-teacher relation as the aspect of having [3]. 
Positive affect in school refers to the frequency of positive emotions experienced, especially during school, such as feeling relaxed, pleasant, fun or happy. Negative affect in school refers to the frequency of negative emotions, such as feeling depressed, upset, having a problem with something or bored in school. Empirical support for this school well-being model has been garnered by Chinese adolescents [2]. Applied to the school context, 'being' can be seen as how the school offers means for self-fulfillment. Each student should be considered to have a contribution as an important member of the school community. It should be possible for each student to participate in the decision-making affecting their schooling and other aspects of the school. Opportunities for improving knowledge and skills emphasizing the student's fields of interest are important. Positive learning experiences enhance the self-fulfillment of the student in school. The amount of respect a student receives from parents', teachers' and peers' is important and contributes to students' lives. Respect is fundamental for studying to be meaningful. Opportunities for leisure time activities during breaks and a close connection with nature act as a counterbalance to work and thus supports self-fulfillment of student [4].

Students need to have possibilities which influence the critical elements of their life, be it their active or leisure time. Opportunities for meaningful working experience and enjoyment of nature are also crucial parts of self-fulfillment. The results of another study found that job satisfaction and performance are related to the right job choice and the existing suitability between personality type and work environment. Individuals with high subjective well-being levels are also shown to have effective skills and behaviours for their career development process. in other word they are more likely to be succeed in the work [5-6]. Appropriate teaching for each student, together with guidance and encouragement, produce these experiences for different kinds of learners.

School, as a place for students to receive various experiences, has encountered many changes in the countries belonging to the Europen Union (as well as Iceland and Norway) in the last two. Over three years (2016-2018), vocationally oriented education and training were implemented in many schools to give them opportunities to prepare for facing the sector today and in the future. Lifelong learning is a new perspective held by vocational education and training.

Instead of going to school, a student will gain vocational skills throughout the working life. The National Education Policy in guiding work life orientation in Finland (National Education Board 2004) lists two main objectives for schoolbased work life orientation, which are expected to have an impact on student development processes.

The strategy to make this happen include bringing schools and the surrounding society closer and facilitating students with choices for future careers and education.

In Indonesia, vocational education and training are accommodated in vocational high schools or vocational schools. Vocational high schools are expected to require many aspects such as developing cognitive, psychomotor and individual learning skills [7]. Schools are also expected to develop student attitudes, develop positive appreciation of work, build work culture, and build learning culture. In addition, the ability to be more innovative, creative, and productive is also needed to prepare students for work, entrepreneurship, and attitude.

Vocational schools must facilitate the fulfillment of all the students, both physically and non physically, morally, and also for their future [8]. In the teaching and learning process in vocational schools, students are expected to prioritize the characteristics of the education system, such as stratification and standardization related to the labor market and the specificity of the work to be taken.

Research in expected vocational effects and expected impacts has yielded different predictions in different theoretical frameworks, including human capital theories, signaling and job queue, and network theories [9]. Some researchers argue that making career decisions involves many aspects, such as the basic ability to use a variety of resources they have both physically and psychologically [10]. Researchers also argue that making decisions about careers can sometimes be stressful. Negative things that can arise if there is a dysfunctional or in other words called a mismatch between the skills possessed by someone with the demands of the job received. Career discrepancies are related to perfectionism, self-esteem, and excessive generalization. Individuals who experience career mismatch can experience decreased life satisfaction and subjective well-being.

Problems related to job satisfaction, poor work performance, job avoidance, job failure, and significant unhappy others or family members have also been related to the manifestation of dysfunctional career behaviours [6]. In Canada, the issue of skills mismatches was one of the big issues aside from the problem of high youth unemployment and underemployment, economic growth, the decline of good quality jobs and the bleak demographic future for some of the trades [11].

In Indonesia, exploration of vocational interests is still not widely known by many people. The right choice of student interests will make students feel comfortable during the teaching and learning process at school. The choice of programs that are of interest to students is able to facilitate students' abilities and creativity, this aims to make students more involved in all educational processes. Holland's theory reveals that student interest is the interaction between humans and the environment. The environment will direct one's ability to become more professional in a particular field, and not rule out the possibility of success. Besides that, it is necessary to identify patterns of interest, to find out the reasons for students who do not enjoy going through the learning process, whether due to misplacement or any other factor. In Indonesia, only a few schools have conducted Psychological Tests to find out students' interests. The test still takes a long time and for the costs are also not cheap.

Satisfaction and job performance are related to the right job choice and suitability between personality type and work 
environment [6, 12-14]. Holland's theory is particularly useful in providing information about individuals and career alternatives that individuals can choose and can help individuals understand their wants and suitability with their work environment $[15,16]$. It is hoped that this paper will contribute to the knowledge of students regarding the importance of appropriate vocational interest and the personality typology of students. Thus students will feel happy and enjoy studying at school and explore their skills maximally.

The development of Holland's typology classification is based on certain patterns of interests termed personality patterns. The intended personality pattern is a representation of the personality type resulting from the individual response to the instrument. This pattern can consist of two to three dimensions in Holland's typology. The pattern of personality type is obtained by uniting two or three of the highest scores on specific dimensions of the six dimensions in Holland's theory to obtain a picture of the vocational interest profile of the individual [17].

From the problem previously stated, this study wants to know the school well-being seen from the vocational interest of students of the manufacturing program. The students whose chosen program has matched their personality typology will have a positive perception of their program hence indicating school well-being.

\section{Methods}

The purpose of the research is to identify the students' interest in vocational schools as the dimension of being in a well-being model school. This study was conducted with 372 students as respondents from 11 vocational schools in Indonesia. All of the students who participated are enrolled in the manufacturing program as their vocational interest. Indonesia offers approximately 142 vocational interest packages. In this research, the focus on manufacturing because it is one of the highly chosen fields in many vocational schools in Indonesia. The data collection used in this study was the vocational interest scale developed by Kumaidi et al., which has been modified into a computer application, the online vocational interest scale which was modified from the standardized scale known as SDS (Self Directed Scale) by Holland [18]. A questionnaire measured the subjective perception among students. The assistance of field assistants conducted the data collection process. Each student was assigned a user id and a password to access the vocational interest scale application at the given website address. The students then filled the scale accordingly to the guidelines of the online application in there each computer laboratory; The scale can be seen in www.psikometriums.com.

Online data retrieval system produces data collected in one server so that in a relatively short time. The data can be collected into one without manual scoring and data input. The vocational interest scale consists of 228 items to reveal the activities, competencies, and dreams of work based on aspects of personality which, according to Holland, is Realistic, Investigative, Artistic, Social, Entrepreneur, and Conventional. The scales also asks several questions related to general data and respondent's demographics. The quesionare is about the respondent's perception of school and how it feels when going through the learning process, the choices of answers consist of four categories, namely enjoy, fun, boring, and challenging.

Data analysis used an average to count the total score using the frequency distribution table, cross-tabulation, and descriptive analysis. In the vocational interest scale developed by Kumadi et al. (2015), the coefficient reliability is between 0,849 to 0,911 . The validity of the vocational interest scale is proven by the inclusion of Realistic, Investigative, Artistic, Social, Enterprising, and Conventional dimensions using the Content Validity Index technique proposed by Aiken. The results of CVI analysis of 216 items from the vocational interest scale showed moderate and average results. Content validity is high if it has an index between $0,90-1,00$; moderate if the index is $0.60-0.89$; and low if $<0.60$. In general, the vocational interest scale has a moderate or average content validity index. The CVI analysis of the vocational interest scale moves from 0.67 to $1.00[18]$.

The researcher using Confirmatory Factor Analysis to indicated The construct validity. The analysis data using Lisrel 8.8 program. The result of the analysis shows that in general, the RMSEA value in each dimension is in the range of $0.05-0.08$ which shows that it is an acceptable item, and the RMSEA value in the Artistic (A) and Conventional (K) dimension is in the range of $0.09-0.10$ which is quite acceptable. The results of this analysis also show that in general, all items have a value of $t>1.96$ indicating that these vocational interest scale items represent the dimensions of RIASEC quite well, it means Holland's typology model can be implemented empirically to measure vocational interest [18].

\section{Result}

The dimension of 'being' in a well-being model school can be seen from subjective and objective indicators. Subjective indicators can be seen in students' perception regarding their personal growth and how they spend their time at school. For vocational students, they must practice and learn about their field; all the knowledge and proficiency will automatically be applied in the workplace. When students are happy and enjoy their ability to appropriately with proficiency in the workplace, they will maximize all the effort to be productive.

Separated between objective and subjective indicators of self-fulfillment, the result in table 1 indicates that from 372 respondents, $49.8 \%$ enjoy studying at school. $21.3 \%$ of the respondents find that there are many fun things that they receive from school, whereas $24.7 \%$ feel that studying mechanical proficiency is challenging, and only $0.9 \%$ of the respondents think that studying in their chosen subject at school is boring. Thus, table 1 indicates that respondents feel 
happy and enjoy school because they like the materials they study at school, although some feel that practicing mechanical engineering expertise in the field is challenging.
Overall, they see the school be fun because of the interactions they have with friends and teachers. Subjective indicator of self-fulfilment can see in table 1 below.

Table 1. Subjective indicator of self-fulfilment.

\begin{tabular}{|c|c|c|c|c|c|c|}
\hline Student answer & Enjoyable & Fun & Boring & Challenging & Not answer & $\mathbf{N}$ \\
\hline Frequency & 185,25 & 79,25 & 3,58 & 91,91 & 12 & 372 \\
\hline Percentage & $49,8 \%$ & $21,3 \%$ & $0,9 \%$ & $24,7 \%$ & $3,3 \%$ & $100 \%$ \\
\hline
\end{tabular}

The categories of appropriateness between the typology of the interests that respondents chose as their vocational interest can be divided into 3 categories: high, average, and low. From the 372 respondents, the finding of this research shows that almost $41.12 \%$ of the respondents fall into the high category, which means that the score of the typology of Mechanical engineering as a vocational interest and the personality typology of the students was appropriate (Table 2).

Table 2. Appropriate between the typology of interest student and standard typology in mechanical as a vocational interest.

\begin{tabular}{lll}
\hline Appropriate category & Frequency & Percentage \\
\hline High & 153 & $41,12 \%$ \\
Average & 125 & $33,62 \%$ \\
Low & 94 & $25,26 \%$ \\
N & 372 & $100 \%$ \\
\hline
\end{tabular}

\section{Discussion}

The appropriateness between the vocational interest and typology interest of students can predict one of the dimensions in school well-being, both in the subjective and objective indicator of 'being' (fulfilment). The placement of students in a certain field of expertise requires proper identification so that there is accuracy between the typology of interest and the individual. The hexagonal Theory of RAISEC by Holland has been widely used and applied in the development of vocational interest instruments. Several interest instruments that have been developed based on Holland's theory are SDS, VPI, Strong-Campbell. Holland's theory is called person-environment interaction that tries to match the suitability between individual characteristics and desired work characteristics. The school environment influences students' feelings; thus if the environment makes students happy, they will automatically be happy, and wellbeing at school will happen [19]. The development of Holland's vocational interest scale to explore students' career opportunities from when they are still in Junior High Schools. Identification of student interest can be used to address problems in determining advanced education options [20]. Vocational interest can serve as a predictor in determining a person's inclination towards students high school to vocational interest with various combinations of skills program.

\section{Conclusion}

In the school well-being theory, personal perception is extremely important in order to know how students feel about their school. When the students enjoy studying at school, it can be a positive psychology for the student [21]. Positive felling can improve self- efficacy, self-esteem and optimism that is needed for students [21]. Especially in vocational schools, in vocational schools students are required to master the skills associated with the work they will do. when students feel happy when studying certain skills it will help students become more stable in their career development. The education process at school becomes a provision for students to carry out work life because they are required to chose only one vocational interest as their field of study. The relation between wellbeing and career development is such as that of reciprocal interaction [20]. Students need to enjoy their study at school for them to be happy, and the subjective well-being will increase. Factors that indicate well-being is not only seen from one dimension of vocational interest but all bases of this interest. Knowing that the right vocational interest was chosen will predict the students' feeling of enjoyment at school and have a positive correlation on career development. Well-being at school encourages students to be more creative in thinking, friendly, energetic, optimistic, more productive, stronger immune system, healthier, and live longer.

\section{List of Abbreviation}

1. SDS: self-directed search.

2. CVI: Content Validity Index.

3. RIASEC: Realistic, Investigative, Artistic, Social, Entrepreneur, and Conventional.

4. RMSEA: Root Mean Square Error of Approximation.

5. VPI: Vocational Preference Inventory.

\section{References}

[1] A. Konu, E. Alanen, T. Lintonen, and M. Rimpela, "Factor structure of the School Well-being Model," vol. 17, no. 6, pp. 732-742, 2002.

[2] L. Tian, B. Liu, S. Huang, and E. S. Huebner, "Perceived Social Support and School Well-Being Among Chinese Early and Middle Adolescents: The Mediational Role of SelfEsteem," Soc. Indic. Res., vol. 113, no. 3, pp. 991-1008, 2013.

[3] A. Alsa, aniq hudiyah B. Haq, A. jannah Siregar, A. kusumaningrum Fitri, H. dyah Utami, and R. dewi Bachria, "Menyusun Model yang Efisien dan Efektif dari Memprediksi Prestasi Belajar Matematika," J. Psikol., vol. 42, no. 1, pp. 15-33, 2015. 
[4] A. Konu and M. Rimpelä, "Well-being in schools: A conceptual model," Health Promot. Int., vol. 17, no. 1, pp. 79$87,2002$.

[5] R. C. Reardon and J. G. Lenz, "Holland's Theory and Career Assessment," J. Vocat. Behav., vol. 55, no. 1, pp. 102-113, Aug. 1999.

[6] D. R. Strauser, D. C. Lustig, and A. Çiftçi, "Psychological Well-Being: Its Relation to Work Personality, Vocational Identity, and Career Thoughts," J. Psychol., vol. 142, no. 1, pp. 21-35, 2008.

[7] I. J. H. van Emmerik, A. B. Bakker, and M. C. Euwema, "Explaining employees' evaluations of organizational change with the job-demands resources model," Career Dev. Int., vol. 14, no. 6, pp. 594-613, 2009.

[8] P. Iswanto, "The Development of the Values Education in Vocational High School in Indonesia," Int. J. Vocat. Educ. Train. Res., vol. 1, no. 1, p. 1, 2015.

[9] K. Friberg, "Apprenticeship orientation as planned behavior in educational choices : a path model of antecedent beliefs," no. 1975, pp. 1-14, 2014.

[10] A. L. Monson, "Characteristics of Dental Hygienists based on Holland's Career Choice Theory," vol. 86, no. 2, pp. 141-150, 2012.

[11] T. Gremaud, "Vocational education in Canada," J. Vocat. Educ. Train., vol. 69, no. 2, pp. 282-285, 2017.

[12] Cedefop, The changing nature and role of vocational education and training in Europe Volume 2: results of a survey among European VET experts, vol. 2. 2017.
[13] G. Nagy, M. Vock, and K. Olaf, "Vocational interests of intellectually gifted and highly achieving young adults," pp. 305-328, 2013 .

[14] S. Neuman and A. Ziderman, "Vocational Schooling, Occupational Matching, and Labor Market Earnings in Israel," vol. 26, no. 2, pp. 256-281, 2014.

[15] G. Gottfredson and M. Johnstun, "John Holland's contributions: A theory-ridden approach to career assistance," Career Dev. Q., vol. 58, no. December, pp. 99-107, 2009.

[16] C. S. Wong, P. M. Wong, and K. Z. Peng, "An exploratory study on the relationship between parents' career interests and the career interests of young adults," Int. J. Educ. Vocat. Guid., vol. 11, no. 1, pp. 39-53, 2011.

[17] H. Y. Liao, P. I. Armstrong, and J. Rounds, "Development and initial validation of public domain Basic Interest Markers," $J$. Vocat. Behav., vol. 73, no. 1, pp. 159-183, 2008.

[18] K. Kumaidi, R. Farida, and A. hudiyah B. Haq, "Skala Minat Kejuruan : Strategi Mengenali Minat Vokasi Siswa," 2017, pp. 553-562.

[19] S. Göksoy, "Situations That Make Students Happy and Unhappy in Schools," Univers. J. Educ. Res., vol. 5, no. 12, pp. 77-83, 2017.

[20] A. Hirschi, "Effects of Orientations to Happiness on Vocational Identity Achievement," career Dev. Q., vol. 59, no. 4, pp. 367-378, 2011.

[21] A. Shoshani and S. Steinmetz, "Positive Psychology at School: A School-Based Intervention to Promote Adolescents' Mental Health and Well-Being," J. Happiness Stud., vol. 15, no. 6, pp. 1289-1311, 2014. 